\title{
Kronikk:
}

\author{
Jonas Velde
}

Universitet i Agder

\section{Få TV-serier inn i engelskfaget}

Unges høye ukentlige forbruk av TV-serier via strømmetjenester bør i større grad inkluderes og utnyttes i skolen, spesielt i engelskklasserommet.

Det har lenge vært klart at unge bruker mye tid på serier. I en undersøkelse av Medietilsynet $^{1}$ i 2018 om medievaner og tidsbruk blant norske 13-18-åringer, fremkommer det at $57 \%$ av de spurte hadde brukt strømmetjenester dagen i forveien.

I aldersgruppen 16-18 år var videre andelen som brukte strømmetjenester 2 timer eller mer per dag på 27,33\% blant jentene og 18,33\% blant guttene. Tilsvarende tall for tidsbruk på lineære TV-kanaler var på henholdsvis $4,33 \%$ blant jentene og 1,67\% blant guttene.

Når det gjelder lesing av romaner og annen skjønnlitteratur, virker tallene mørkere. En unders $\varnothing$ kelse av Norstat for $\mathrm{NRK}^{2}$ i 2019 viser at én av fire unge «gidder ikke lese bøker», og at «bøker ikke er relevante for dem». I alderen 15-25 år rapporteres det at 74\% leser færre enn 5 bøker i året.

Silje Tretvoll, daglig leder i foreningen !les er ifølge NRK ikke overrasket, men hevder følgende om viktigheten av at barn og unge leser: «Litteraturen kan skape kulturelle fellesskap og felles referanserammer. Ved å lese bøker skaper man kritiske lesere, som kan skille mellom fakta og fiksjon.»

En slik fremheving av verdien av skjønnlitteratur for både individet og fellesskapet er Tretvoll langt ifra alene om å ta til orde for. Den har tvert imot lenge lagt grunnlaget for både litteraturinnholdet i læreplaner og satsinger på nasjonale lesekampanjer.

Lesing av fiksjon og fortellinger er så klart viktig av ulike årsaker, men man kan spørre om nevnte kritiske leseevne og «kulturelle fellesskap og felles referanserammer» utelukkende kommer fra skjønnlitteraturen. En vilkårlig spurt person på gata vil kanskje like gjerne eller snarere trekke frem kritiske perspektiver på nye TV-serier på Netflix, HBO Nordic og Viaplay, som en tidligere eller nålevende forfatters verker.

Med tanke på hvor mye tid barn og unge (for ikke å si voksne) bruker på TV-serier er det viktig å ikke ta disse kulturuttrykkene for gitt, men snarere anerkjenne dem og bli mer kritisk til hva de eventuelt kan lære oss. I boken Media Messages - What Film, Television and Popular Music Teach Us About Race, Class, Gender and Sexual Orientation drøfter forfatterne i detalj hvordan nevnte underholdningsmedier påvirker oss.

\footnotetext{
${ }^{1}$ https://www.medietilsynet.no/globalassets/dokumenter/trygg bruk/barn-og-medier-2018/barn-og-medier2018-medievaner-mobil--og-tidsbruk.pdf

${ }^{2}$ https://www.nrk.no/kultur/en-av-fire-unge-gidder-ikke-lese-boker-1.14542046
} 
TV-serier skaper og former vår erkjennelse av person- og gruppeidentitet, hva vi oppfatter som «normalt», samt vår forståelse av individer og grupper som er annerledes enn oss selv, og de inviterer oss til å gå utover våre egne subjektive rammer og erfaringer. Vi «lærer» altså mye passivt fra serier, men kunne med fordel innta mer kritiske tilnærminger til hva disse formidler, slik skolen allerede gjør med bøker, film, reklame og sosiale medier, for å nevne noen.

Som tidligere engelsklærer i videregående erfarte jeg selv elever som uttrykket motstand mot lesing av romaner i engelskfaget, og at de fikk lite ut av det. I samtaler med de samme elevene i pauseprat på norsk registrerte jeg stor entusiasme for mange kritikerroste TV-serier, og i mange tilfeller dyptgående muntlige analyser av handlingstrekk eller utvikling av karakterer, m.m.

Kan man trekke slike serier inn i klasserommet og utnytte denne motivasjonen for skriftlig og muntlig kommunikasjon og refleksjon rundt meningsinnhold? Mange elever sliter med motivasjon for romanlesning og -analyse, men hvis de serveres tilsvarende sofistikerte og engasjerende narrativer i serieformat tyder mye på at motivasjon og potensiale for analytisk dybde er høy.

Ungdomsserien «SKAM», som gikk på NRK fra 25. september 2015 til 24. juni 2017, er et fremtredende eksempel på en norskprodusert TV-serie som ikke bare nådde ungdommen, men ble et landsdekkende fenomen. Våren 2017 ble serien inkludert i oppgavesettet til eksamen ${ }^{3}$ i norsk hovedmål for VG3, med linjer fra Henrik Ibsens Nora Helmer til SKAMs Noora Sætre. Våren 2018 utga Fagbokforlaget boka Dramaserien Skam - Analytiske perspektiver og didaktiske muligheter, med fagtekster om hvordan serien kan brukes i norskfaget, samfunnsfag, og religion og etikk.

I mitt pågående doktorgradsprosjekt «Teaching with TV-Series» (arbeidstittel) utforsker jeg tilsvarende didaktiske muligheter for bruk av TV-serier i programfaget Samfunnsfaglig engelsk på 3. år i videregående skole. Det finnes mange kritikerroste og prisvinnende serier på strømmetjenester som Netflix og HBO som gir innblikk i ulike sider ved britisk og amerikansk samfunn, både historisk og i nåtid, men for mitt prosjekt har jeg valgt Netflixserien «Orange is the New Black».

Med sjuende og siste sesong sluppet på Netflix i juli 2019, har serien siden lanseringen i 2013 vært en seer- og kritikersuksess. Handlingen utspiller seg i et fiktivt amerikansk lavsikkerhetsfengsel, og består av et rikt karaktergalleri av ulike kulturelle-, sosiale-, $\emptyset$ konomiske- og kjønnsbakgrunner.

Relasjonene og konfliktene som oppstår mellom disse karakterene fra dag til dag kombinerer engasjerende dramakomedie med en bunnlinje av systemkritikk av USAs kriminalpolitikk og fengselsvesen. Disse kan, i kombinasjon med lesing av ulike autentiske sakprosatekster som gir kontekst for handlingen, gi grunnlag for interessant skriftlig og muntlig aktivitet i klasserommet som samtidig legger grunnlag for dypere innsikt i sider ved det amerikanske systemet.

\footnotetext{
${ }^{3}$ https://www.aftenposten.no/kultur/i/yAAMA/i-aar-var-eksamensoppgaven-saa-god-at-elevene-diskutererden-frivillig-e
} 
En slik bruk av serier i klasserommet kan øke motivasjon for unge i arbeid med narrativforståelse ved å trekke ting de er opptatt av inn i klasserommet. Samtidig kan det også gi lærere, særlig i videregående skole, utvidete verktøy å ta i bruk i klasserommet for å belyse sider av engelskspråklige samfunn ved kobling av sakprosa og populærkultur. 